\title{
Analisis Kemampuan Berpikir Kritis Matematis yang Ditinjau dari Self Efficacy Siswa Dalam Pembelajaran Daring
}

\author{
Reni Astari Hidayat ${ }^{1}$, Sri Hastuti Noer ${ }^{2}$ \\ ${ }^{1,2}$ Program Studi Pendidikan Matematika FKIP Universitas Lampung \\ Penulis Korespondensi: hastuti_noer@yahoo.com
}

\begin{abstract}
: the aim of study is to analyze mathematical critical thinking abilities in term of learners' selfefficacy $i$ online learning process. This research is qualitative research that using descriptive approaches. This research subjects were learners of class VII-1 SMPN 45 Bandar Lampung that consisted of 25 learners. The research instrumens were observations of online learning, then questionnaire self-efficac, and the test description of the critical thinking ability. This research showed esults several results that learners who have a low self efficacy were learners who have a low mathematical critical thinking ability then conversely learners who have a high self efficacy were learners who have a good critical thinking skills in online learning.
\end{abstract}

Keywords: online learning, self-efficacy, critical thinking abilities

Abstrak: Tujuan penelitian yaitu untuk menganalisis terkait kemampuan dalam berpikir kritis yang mana ditinjau dari self efficacy anak didik dalam pelaksanaan pembelajaran sedang online. Jenis dari penelitian adalah penelitian kualitatif dengan pendekatan deskriptif. Adapun subjek dalam penelitian ialah siswa kelas VII-I SMPN 45 Bandarlampung yang berjumlah 25 siswa. Instrumen penelitian menggunakan lembar observasi terhadap pembelajarang secara daring, kemudian lembaran angket self efficacy serta tes uraian terkait soal kemampuan dalam berpikir secara kritis. Penelitian menunjukkan hasil yaitu siswa dengan self efficacy rendah mempunyai kemampuan berpikir secara kritis matematis rendah, kemudian sebaliknya siswa dengan self efficacy yang tinggi mempunyai kemampuan dalam berpikir kritis yang baik dalam proses pembelajaran secara daring.

Kata Kunci: Pembelajaran Daring, Self Efficacy, Kemampuan Berpikir Kritis

\section{PENDAHULUAN}

Dunia digemparkan dengan wabah Covid-19 yang mana wabah tersebut juga menyerang Indonesia. Adanya wabah virus ini tidak hanya memberikan dampak dalam sektor kesehatan, namun juga sektor pendidikan. Pembelajaran pada masa Covid-19 mengharuskan pembelajaran tanpa tatap muka atau Study From Home. Hal ini diperkuat oleh penuturan Luh, et al. bahwa pembelajaran dirumah dengan fasilitas penunjang menjadi solusi (Herliandry et al., 2020). Pembelajaran tanpa tatap muka yang mana dilaksanakan secara online. Pelaksanaan pembelajaran daring ini memanfaatkan platform yang mendukung proses pembelajaran (Handayani, 2020). Pembelajaran bisa memanfaatkan platform online seperti grup whatsapp, google classroom, schoology, etmodo, dan sebagainya (Assidiqi \& Sumarni, 2020; Gideon, 2020). Dalam belajar daring, baik guru maupun siswa perlu melakukan penyesuaian. Hal itu terjadi karena belajar daring merupakan suatu kebiasaan baru bagi sistem pendidikan di Indonesia. Akibatnya dari hal tersebut tentunya menimbulkan tantangan termasuk kesulitan belajar bagi siswa. Kesulitan belajar adalah ketidakmampuan siswa untuk memahami konsep, prinsip, dan keterampilan baik secara internal maupun eksternal (Hadiprasetyo et al., 2020). 
Berdasarkan penelitian terhadap 30 siswa SMA diketahui bahwa kesulitan belajar daring matematika mencapai 75\% (Utami et al., 2020). Faktor yang memengaruhi hal tersebut adalah kendala signal serta kurang ada pemahaman terhadap belajar online dan kurangnya interaksi, tugas yang terlalu banyak serta bahan ajar yang kurang memadai. Selanjutnya dari hasil penelitian terhadap 51 siswa SMP diketahui bahwa kesulitan belajar daring matematika yakni diakibatkan karna adanya: 1) keterbatasan ruang untuk melaksanakan interaksi diantara pendidik dan siswanya, 2) terdapat banyak rumus, 3) objek yang dipelajari berhubungan dengan pola abstrak (Fauzy \& Nurfauziah, 2021). Permasalahan tersebut mengakibatkan siswa menjadi kesulitan dalam memahami berbagai materi bidang studi matematika yang diajarkan sehingga mereka mudah menyerah saat dihadapkan dengan persoalan yang cukup sulit.

Matematika menjadi ilmu dasar penting untuk dipelajari diseluruh tingkatan, yang mana dimulai dari jenjang TK hingga perguruan tinggi. Sebagaimana juga yang diungkapkan oleh Nicky yang menjabarkan matematika sebagai ilmu pengetahuan yang mana dipelajari dibangku sekolah (Puspaningtyas, 2019). Ufi, Helti \& Danang, matematika merupakan ilmu yang penting (Dwidarti et al., 2019). Matematika adalah salah satu bidang studi yang berpengaruh sehingga harus diberikan kepada seluruh siswa disetiap jenjang agar mempunyai kemampuan berpikir secara analitis, logis, kreatif, sistematik maupun kritis (Depdiknas, 2006). Oleh karena itu, ketika berada dalam pembelajaran matematika siswa diharapkan mampu mengembangkan setiap keterampilan dalam berpikir.

Sejalan dengan itu, pembelajaran abad 21 menuntut kepada penguasaan terhadap $4 \mathrm{C}$ atau disebut dengan communication, collaboration, critical thinking \& problem solving, creativity \& innovation yaitu sebagai keterampilan anak didik untuk berkomunikasi dan berkolaborasi, mampu dalam berpikir kritis, mengaitkan dan menerapkan ilmu dengan kehidupan sehari-hari serta menguasai ilmu teknologi dan informasi. Akan tetapi, sampai dengan saat ini matematika dianggap sebagai hal rumit dan kurang diminati bahkan sampai dianggap menakutkan untuk sebagian banyak siswa. Hal itu dikarenakan di dalam matematika memuat banyak rumus, definisi serta berbagai jenis soal sehingga siswa merasa tidak yakin, cemas, dan kesulitan dalam menyelesaikan masalah matematika.

Menyelesaikan masalah tersebut diperlukan adanya kemampuan berpikir yang bertujuan mengembangkan kemampuan berpikir, yakni salah satunya apabila mempunyai keterampilan dalam berpikir kritis. Yang mana keterampilan tersebut dipergunakan untuk dapat mengembangkan kemampuan berpikir lainnya, sehingga hal ini sangat penting untuk dimiliki dalam keseharian, seperti dalam membuat keputusan serta penyelesaian suatu masalah (Agusman, 2016; Muhtadi et al., 2019; Nurazizah \& Nurjaman, 2018). Konsep dari berpikir kritis yakni menekankan untuk berpikir secara rasional dalam menentukan keputusan. Yang mana berarti pada saat menyelesaikan permasalahan harus adanya pertimbangan secara rasional sehingga dapat menentukan mana yang akan dijadikan solusi dalam menyelesaikan masalah yang ada (Ennis, 1996). Secara lebih lanjut, berpikir kritis yakni berarti keterampilan dalam membuat keputusan secara lebih rasional tentang apa yang harus dilaksanakan atau dipercaya (Slavin, 2006). Kemudian, menurut PA Facione berpikir kritis adalah kegiatan pengambilan keputusan berdasarkan bukti, konsep, metode, kriteria dan kondisi, dan tergantung pada tujuan membuat interpretasi, analisis, evaluasi dan kesimpulan (Hendriyana et al., 2017), (Noer, 2018b). Dalam berpikir kritis, semua keterampilan ditingkatkan, baik dalam memahami, mengingat, menganalisa, menalar, menafsirkan, menemukan relasi, mengevaluasi ataupun membuat pernyataan. 
Melatih kemampuan sehingga mampu berpikir secara kritis memungkinkan mereka untuk mempertimbangkan semua masalah dalam hidup mereka. Berpikir kritis dapat membuat siswa lebih peka terhadap situasi, sehingga siswa dapat mengorganisasikan informasi yang diterimanya. Berpikir kritis dapat disebut sebagai keterampilan berpikir untuk mengidentifikasi keputusan/ tindakan dimana keterampilan berpikir kritis berbeda secara nyata pada peserta didik. Oleh karenanya, tenaga pendidik seharusnya mampu mengembangkan keterampilan dalam berpikir kritis dalam aktivitas pembelajaran. Menurut Ennis (Hendriana et al., 2017), secara khusus terdapat berbagai indikator dalam berpikir kritis antara lain: a) titik fokus kepada pertanyaan, b) melalukan analisa serta penafsiran terhadap pertanyaan, argument mapun jawaban, c) melakukan peninjauan terhadap sumber terpercaya, d) kemudian menarik serta menganalisis kesimpulan, e) melakukan analisis induktif, f) membuat rumusan penjelasan, menentukan hipotesis dan kesimpulan, g) mensintesis berbagai pertimbangan yang dianggap valid, h) melaksanakan interaksi dengan individu lainnya. Selanjutnya, (Noer, 2018a) mempertunjukkan berbagai kemampuan berpikir kritis yang meliputi: 1) mengeksplorasi, 2) mengindentifikasi dan menjastifikasi konsep, 3) menggeneralisasi, dan 4) mengklarifikasi dan resolusi. Sedangkan, Facione menjelaskan keterampilan berpikir kritis yang akan melibatkan kegiatan, seperti menafsir, analisis, evaluasi, sintesis, interpretasi hasil berpikir seseorang dan bagaimana membuat keputusan dan menerapkan pengetahuan baru (Solikhin \& Fauziah, 2021).

Dalam menyelesaikan masalah matematika, selain memiliki kemampuan kognitif diperlukan juga sikap percaya diri akan kemampuannya dalam memecahkan masalah. Keyakinan yang dimiliki siswa dalam melakukan tugas tertentu yang sering disebut self efficacy (Bandura, 1997). Selain itu, pemecahan masalah matematika dapat diselesaikan dengan kemampuan afektif yaitu self efficacy (Indahsari et al., 2019). Maka dari itu untuk menyelesaikan permasalahan matematika, kemampuan berpikir kritis dan self efficacy sangat diperlukan. Hal ini dikarenakan, permasalahan matematika berkaitan erat dengan proses sistematis dalam menghasilkan sesuatu yang benar. Peserta didik yang di dalam dirinya mempunyai self efficacy tinggi maka akan berusaha lebih maksimal apabila dibandingkan dengan peserta didik dengan self efficacy rendah. Self efficacy tersebut ikut menentukan kepercayaan diri mereka terhadap kemampuannya dalam menyelesaikan aktivitas belajarnya yang mana untuk mencapai hasil optimal. Peserta didik yang mempunyai self efficacy secara mudah mampu memotivasi diri sendiri untuk terus belajar (Hasmatang, 2019). Selanjutnya, self efficacy akan memiliki berbagai efek, diantaranya: a) membuat perencanaan atas tindakan yang akan dilakukan, b) seberapa besar usaha yang diakan diberikan, c) resistensi terhadap berbagai kesulitan, d) resiliensi terhadap berbagai kegagalan, e) membentuk pola pemikiran, f) depresi, serta g) pencapaian yang akan diraih (Hendriana et al., 2017).

Penerapan pembelajaran daring tentu saja menjadi pengalaman dan kebiasaan baru bagi siswa yaitu siswa dituntut untuk dapat belajar dari jarak jauh. Hal ini membuat tingkat keinginan terus belajar, sifat mandiri dan dukungan keluarga berpengaruh dalam hasil pembelajaran (Sari, 2020). Terlebih lagi kurangnya interaksi dengan lingkungan sekolah dapat membuat siswa kesulitan mendapat motivasi belajar. Individu yang mempunyai self efficacy tinggi lebih mudah dapat menciptakan keinginan tinggi dalam belajar, mempunyai kepercayaan diri akan kemampuannya, tidak mudah menyerah dalam mencari solusi serta mampu mengontrol dan mengembangkan usahanya dalam kondisi yang menjadi tantangan seperti belajar daring. 
Berpikir kritis menjadi sebuah kemampuan berpikir tinggi. Sebagaimana yang disampaikan oleh Suharna, dkk. bahwasannya berpikir secara kritis adalah suatu kemampuan dalam menganalisa, memanipulasi serta melakukan berbagai evaluasi terhadap materi yang telah diterima untuk menentukan kesimpulan dari sebuah permasalahan (Hartini et al., 2018; Suharna \& Abdullah, 2020). Sehingga mempunyai keterampilan berpikir secara kritis harus terus dimiliki selama proses pembelajaran. Siswa yang dapat berpikir kritis akan lebih mudah dalam menuntaskan semua persoalan yang diberikan. Siswa dapat menganalisis soal, merencanakan langkah yang diambil, menyimpulkan dan mengevaluasi. Hal ini penting karena saat pembelajaran daring, lemahnya pola interaksi antara tenaga pendidik dengan peserta didiknya, kemudian mereka mempunyai sifat pemalu untuk mengajukan pertanyaan dari tugastugas yang diemban.

Berdasarkan kasus di atas, maka perlu dilakukan analisis terkait keterampilan dalam berpikir kritis matematis yang ditinjau dari aspek self efficacy peserta didik khususnya pada saat pelaksanaan pembelajaran online. Analisis dalam keterampilan berpikir kritis ini mengacu kepada penyebab kesulitan berpikir tinggi serta kurangnya kepercayaan diri terhadap kelebihan yang dimiliki oleh siswa kelas VII SMPN 45 Bandarlampung. Sehingga hal tersebut mendorong peneliti merasa tertarik untuk menganalisis kemampuan berpikir secara kritis siswa yang ditinjau dari self efficacy pada pelaksanaan pembelajaran secara daring.

\section{METODE}

Dalam pelaksanaan penelitiannya, peneliti menggunakan metode deskriptif kualitatif dengan instrumen penelitian yang digunakan yaitu tes dan non tes. Dalam instrumen non tes meliputi observasi dan juga angket, pelaksanaan observasi dilaksanakan untuk pembelajaran secara daring, sedangkan angket yang digunakan adalah angket mengenai self efficacy sebagai upaya untuk mengetahui tingkat self efficacy dari setiap siswa dengan memberikan 20 butir pertanyaan positif maupun negatif yang telah dirinci menggunakan magnitude, strength, dan generality. Adapaun untuk mengukur self efficacy ialah dengan menggunakan skala likert.

Tabel 1. Skala penilaian pada angket self efficacy

\begin{tabular}{ccc}
\hline Alternatif Jawaban & positif & Bobot nilai \\
\cline { 2 - 3 } SS (sangat setuju) & 4 & negatif \\
S (setuju) & 3 & 1 \\
TS (tidak setuju) & 2 & 3 \\
STS (sangat tidak setuju) & 1 & 4 \\
\hline
\end{tabular}

Dalam instrumen tes menggunakan empat soal uraian yang telah disusun berdasarkan pada indikator dalam berpikir secara kritis, diantaranya: 1) menyediakan berbagai pejelasan sederhana, 2) taktik maupun strategi, 3) membuat penjabaran secara lebih lanjut, 4) menyimpulkan subjek penelitian yaitu 25 pesera didik kelas VII SMPN 45 Bandarlampung dengan jumlah populasi yakni keseluruhan siswa kelas VII. Langkah pertama pada proses pemilihan subjek penelitian adalah dengan menentukan kelas yang dijadikan kelas penelitian, dalam hal ini adalah kelas VII-1, selanjutnya mendistribusikan angket mengenai self efficacy via google form, kemudian langkah selanjutnya menetapkan tingkat self efficacy peserta didik menjadi tiga kelompok yang dibagi ke dalam kelompok tingkat self efficacy caranya dengan membagi berdasarkan pada jumlah skor yang didapatkan yang selanjutnya dikonversikan ke 
dalam kategori rendah, sedang serta tinggi berdasarkan ketentuan yang diperoleh dari langkahlangkah berikut (Ramadhani, 2020):

Tabel 2. Pengelompokan self efficacy

\begin{tabular}{cc}
\hline Tingkat self efficacy & Kriteria \\
\hline tinggi & siswa dengan perolehan skor self efficacy $\geq \bar{X}+$ SD \\
\hline sedang & siswa dengan perolehan skor self efficacy apabila diantara kurang \\
& dari $\bar{X}+$ SD dan lebih lebih dari $\bar{X}-$ SD \\
\hline rendah & Siswa dengan perolehan skor self efficacy $\leq \bar{X}-$ SD \\
\hline
\end{tabular}

Analisis data yang dilakukan berupa reduksi data, penyajian data serta penarikan kesimpulan. Kegiatan analisis data kualitatif dilaksanakan secara interaktif kemudian terlaksana secara berkelanjutan hingga selesai, maka diperoleh data jenuh (Miles dan Huberman, 1992). Kemudian diakhir kegiatan analisis, penulis membuat kriteria dalam penilaian kemampuan berpikir secara kritis metematis yang mana berdasarkan pada klasifikasi tingkat self efficacy siswa atau peserta didik dengan 3 kategori. Setiap siswa menggunakan masing-masing kriteria penskoran pada tabel berikut (Arikunto, 2019):

Tabel 3. Kriteria dalam penilaian kemampaun berpikir secara kritis

\begin{tabular}{cc}
\hline skor & kriteria \\
\hline $\mathbf{8 0} \leq \boldsymbol{P} \leq \mathbf{1 0 0}$ & sangat tinggi \\
\hline $\mathbf{6 0} \leq \boldsymbol{P}<\mathbf{8 0}$ & tinggi \\
\hline $\mathbf{4 0} \leq \boldsymbol{P}<\mathbf{6 0}$ & cukup \\
\hline $\mathbf{0} \leq \boldsymbol{P}<\mathbf{4 0}$ & rendah \\
\hline
\end{tabular}

\section{HASIL DAN PEMBAHASAN}

Tujuan dari pelaksanaan penelitian yakni untuk dapat menganalisis terkait keterampilan berpikir secara kritis yang mana ditinjau dari aspek self efficacy dalam proses pembelajaran secara daring. Dengan hasil data penelitian yakni dikategorikan menjadi tinggi, sedang, dan rendah dari self efficacy siswa, analisis bagaimanakah kemampuan berpikir secara kritis matematis siswa berdasarkan pada kategori self efficacy siswa kemudian membuat presentase kemampuan berpikir secara kritis matematis berdasarkan kategori tingkat self efficacy siswa berdasarkan pada tiga kategori. Hasil dari pendistribusian angket self efficacy pada 25 siswa dapat dilihat pada tabel di bawah ini:

Tabel 4. Pengkategorian self efficacy

\begin{tabular}{ccc}
\hline Tingkat & siswa & \% \\
\hline Tinggi & 3 & $12 \%$ \\
\hline Sedang & 15 & $60 \%$ \\
\hline Rendah & 7 & $28 \%$ \\
\hline
\end{tabular}

Kemudian untuk dapat melihat bagaimana tingkat kesulitan siswa pada saat menyelesaikan permasalahan dalam berpikir secara kritis matematis yang ditinjau dari aspek self efficacy siswa akan digambarkan oleh peneliti dengan cara membuat perbandingan dari beberapa jawaban siswa dengan kategori self efficacy tinggi, sedang maupun rendah. Kemudian berdasarkan pada pengkategorian siswa, sehingga dipilih sebanyak 3 orang siswa untuk menjadi perwakilan dari masing masing kelompok tingkat self efficacy tinggi adalah (A1), kemudian 
kelompok pada tingkat self efficacy sedang ialah (B1) serta kelompok pad self efficacy rendah ialah $(\mathrm{C} 1)$ yang mana menunjukkan hasil jawaban secara lebih jelas untuk dianalis.

\section{a. Indikator soal nomor 1 adalah memberikan penjelasan secara sederhana}

Soal nomor 1 merupakan indikator 1 memberikan penjelasan sebagai berikut:

Perhatikah gambar berikut!

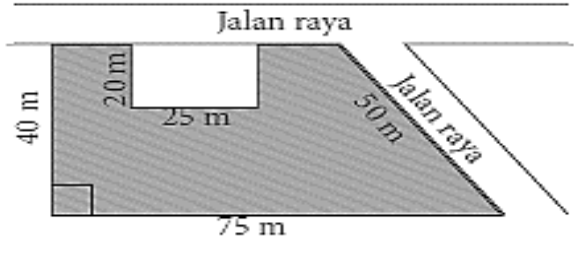

Pada daerah diarsir merupakan sketsa tanah yang ditamani dengan rumput. Maka luas dari hamparan rumput adalah ... (berikan penjelasan atau prinsip yang digunakan)

1) Analisis Jawaban siswa menggunakan self efficacy tinggi (A1)

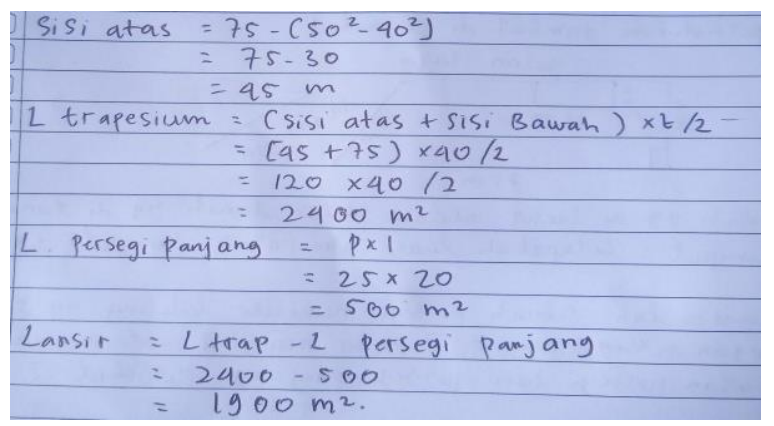

Gambar 1. Jawaban dengan self efficacy tinggi pada soal 1

Berdasarkan gambar di atas menunjukkan siswa dengan self efficacy tinggi (A1) menjelaskan secara terperinci bagaimana menjawab soal yang diberikan. Siswa menuliskan bagaimana menentukan luas sisi atas, luas trapesium, luas persegi panjang serta menentukan luas arsiran dari gambar yang ditentukan. Siswa dengan self efficacy tinggi (A1) mampu memberikan penjelasan sederhana secara sistematis dalam menjawab luas hamparan rumput dari soal yang ditanyakan, selain itu memberikan kejelasan satuan yang digunakan dalam menentukan konsep luas. Analisis jawaban menunjukkan bahwa siswa dengan kemampuan self efficacy tinggi mampu memberikan penjelasan.

2) Analisis jawaban siswa dengan kemampuan self efficacy sedang (B1)

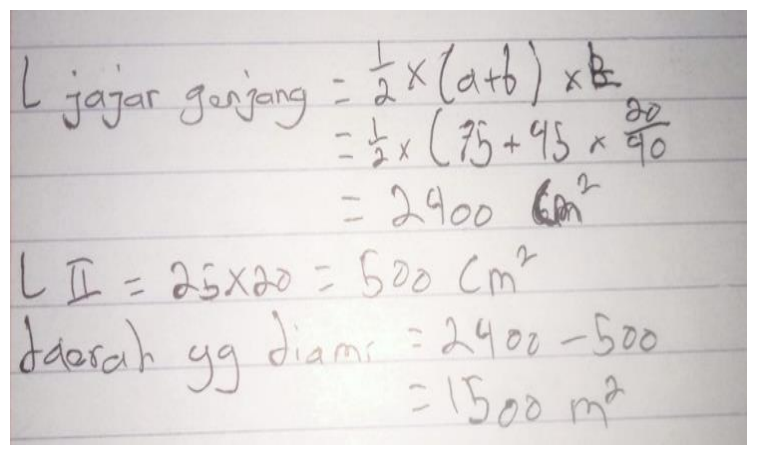

Gambar 2. Jawaban siswa dengan kemampuan self efficacy sedang pada soal 1 
Berdasarkan pada gambar di atas yaitu menunjukkan siswa dengan kemampuan self efficacy sedang mendeskripsikan terkait cara dalam menentukan luas jajar genjang, luas II yaitu luas persegi panjang serta menentukan luas arsiran dari gambar yang ditentukan dengan mengurangi luas jajar genjang dengan luas II. Hanya saja dalam melakukan perhitungan siswa mengalami kesalahan yaitu 2.400 - 500 yang seharusnya 1.900, akan tetapi siswa yang mempunyai self efficacy sedang melakukan kesalahan dengan menulis jawaban 1.500. Selain itu juga, siswa juga memberikan kejelasan satuan yang digunakan dalam menentukan konsep luas. Analisis jawaban menunjukkan bahwasannya siswa dengan kemampuan self efficacy tinggi mampu dalam memberikan penjelasan secara sederhana namun masih terdapat kesalahan pada saat operasi hitung.

3) Analisis jawaban siswa dengan kemampuan self efficacy rendah (C1)

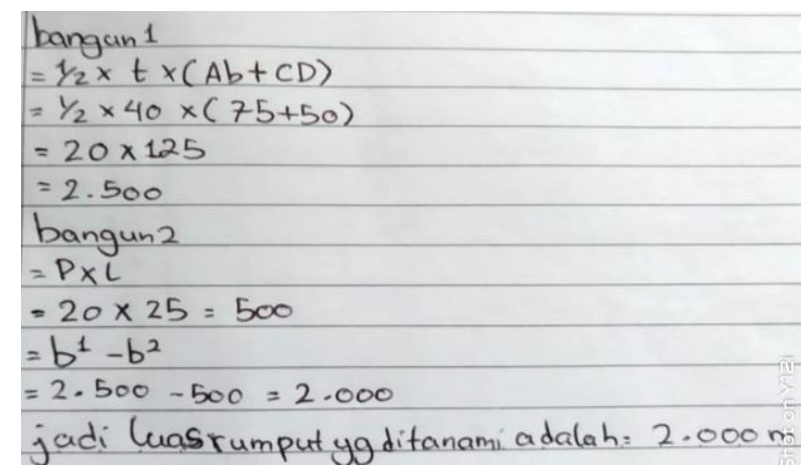

Gambar 3. Jawaban siswa dengan kemampuan self efficacy rendah pada soal 1

Berdasarkan gambar di atas menunjukkan siswa yang berkemampuan self efficacy menuliskan bagaimana cara dalam menentukan luas bangun 1 dan 2 serta mampu dalam menentukan arsiran luas rumput yang ditanami. Namun terdapat kesalahan pada saat menentukan luas bangun 1 dari segi konsep yang dilakukan, penjelasan yang dijabarkan tidak sistematis, kemudian dibagian akhir tidak dapat menyelesaikan soal dan salah menentukan satuan luas pada konsep yang diberikan. Analisis jawaban menunjukkan siwa dengan kemampuan self efficacy rendah tidak mampu dalam memberikan penjelasan secara sederhana.

\section{b. Indikator soal nomor 2 adalah strategi dan taktik}

Soal nomor 2 yang dijadikan sebagai indikator 2 yaitu strategi dan taktik sebagai berikut:

Perhatikan gambar berikut!

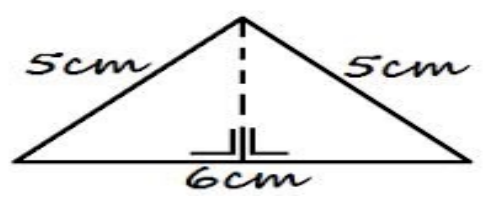

Dari gambar di samping keliling dan luas segitiga adalah... (berikan penjelasan atau prinsip yang digunakan) 
1) Analisis jawaban siswa dengan kemampuan self efficacy tinggi (A1)

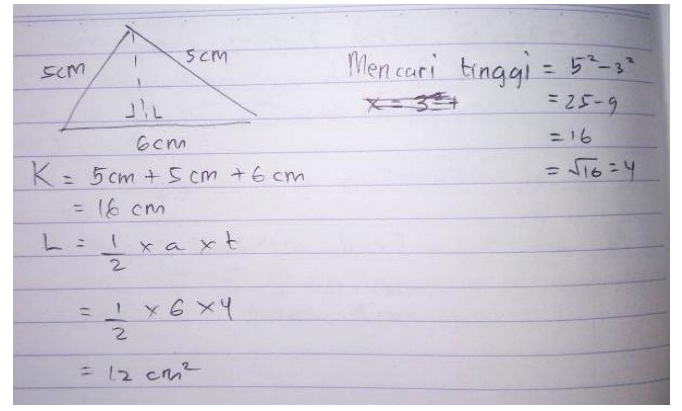

Gambar 4. Jawaban siswa dengan kemampuan self efficacy tinggi pada soal 2

Berdasarkan pada gambar 4 menunjukkan bahwasannya siswa dengan kemampuan self efficacy tinggi memberikan strategi dan taktik dalam proses jawaban secara terperinci pada saat menjawab soal. Siswa tersebut menuliskan bagaimana menuliskan jawaban dari keliling segitiga yang ditentukan pada gambar dengan lengkap meliputi satuan yang digunakan. Selanjutnya, siswa menuliskan konsep rumus luas segitiga dengan terlebih dahulu mencari tinggi segitiga dengan menerapkan konsep Phytagoras dan menggunakan hasil tinggi dalam menentukan luas segitiga tersebut dan diakhiri dengan satuan luas yang benar. Analisis jawaban menunjukkan bahwasannya siswa yang berkemampuan self efficacy tinggi telah mampu dalam memberikan strategi maupun taktik dalam menyelesaikan soal pada indikator 2 .

2) Analisis jawaban siswa dengan kemampuan self efficacy sedang (B1)

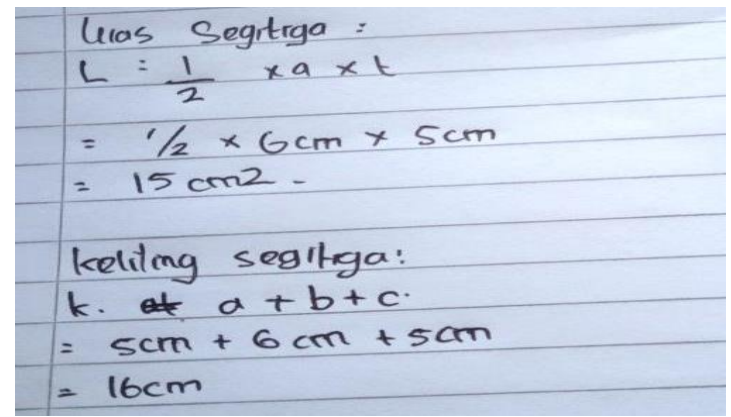

Gambar 5. Jawaban siswa dengan kemampuan self efficacy sedang pada soal 2

Berdasarkan pada gambar di atas menunjukkan siswa yang berkemampuan self efficacy sedang (B1) menuliskan bagaimana hasil jawaban dari keliling segitiga yang ditentukan pada gambar dengan lengkap meliputi satuan yang digunakan. Selanjutnya, siswa menuliskan konsep rumus luas segitiga tetapi siswa tidak mencari tinggi segitiga, siswa menggunakan sisi miring segitiga sebagai tinggi dari segitiga yang ditunjukkan oleh gambar, sehingga jawaban luas menjadi salah. Analisis jawaban menunjukkan bahwasannya siswa dengan self efficacy belum mampu dalam memberikan strategi dan taktik dalam menyelesaikan soal yang diberikan (indikator 2). 
3) Analisis jawaban siswa dengan kemampuan self efficacy rendah (C1)

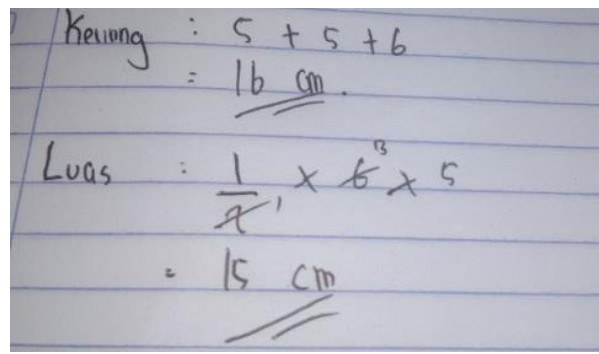

Gambar 6. Jawaban siswa dengan kemampuan self efficacy rendah pada soal 2

Berdasarkan pada gambar di atas menunjukkan siswa yang berkemampaun self efficacy rendah (C1) menuliskan bagaimana hasil jawaban dari keliling segitiga yang ditentukan pada gambar dengan lengkap meliputi satuan yang digunakan. Selanjutnya, siswa tidak menuliskan konsep rumus luas segitiga dan tidak mencari terlebih dahulu tinggi segitiga, siswa menggunakan sisi miring segitiga sebagai tinggi dari segitiga yang ditunjukkan oleh gambar, sehingga jawaban luas menjadi salah. Hasil dari analisis jawaban diketahui siswa dengan kemampuan self efficacy yang rendah tidak cukup mampu dalam membuat strategi maupun taktik dalam menyelesaikan soal yang terdapat dalam indikator 2 .

\section{c. Indikator soal nomor 3 adalah membuat penjelasan secara lebih lanjut}

Soal nomor 3 yang dijadikan sebagai indikator 3 yaitu membuat penjelasan lebih lanjut sebagai berikut:

Suatu proyek direncanakan dapat diselesaikan dalam 12 hari dengan 10 pekerja. Jika pekerjaan tersebut dipercepat 4 hari dari yang telah direncanakan sebelumnya, maka berapa banyak pekerja tambahan yang dibutuhkan ...

1) Analisis jawaban siswa dengan kemampuan self efficacy tinggi (A1)

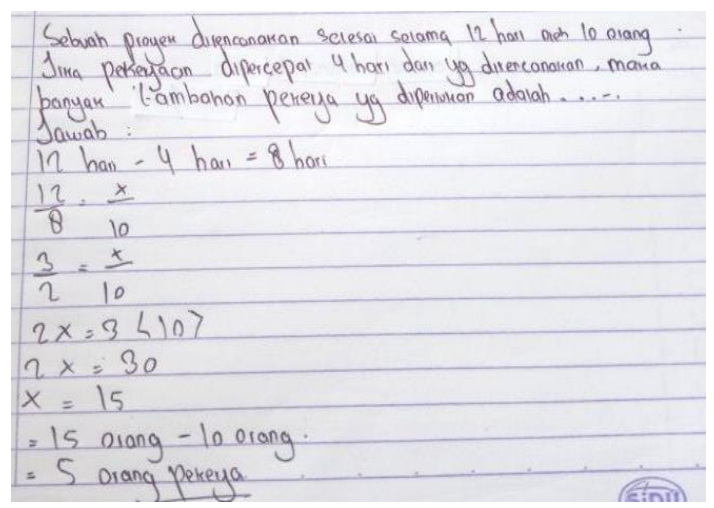

Gambar 7. Jawaban siswa dengan kamampuan self efficact tinggi pada soal 3

Berdasarkan pada gambar di atas menunjukkan siswa dengan kemampuan self efficacy tinggi (A1) mampu memberikan jawaban. Siswa tersebut menuliskan bagaimana prosedur penyelesaian secara sistematis dengan menerapkan konsep yang jelas dan diakhir jawaban memberikan penjelasan bagaimana menentukan penyelesaian secara tepat dan benar. Analisis jawaban menjelaskan siswa yang berkemampuan self efficacy 
tinggi sudah mampu memberi penjelasan lebih lanjut untuk menyelesaikan soal pada indikator 3.

2) Analisis jawaban siswa dengan kemampuan self efficacy sedang

12 hari $=10$ pekerjo
d hari $=x$ pekerja
perbondingan berbalik nilai
$12 / 8=x / 10$
$x=12 \times 10: 8$
$x=120: 8$
$x=15$ pexerja.
jadi banyaknya tambahon odaloh:
15 - 10
$=5$ pekerja.

Gambar 8. Jawaban siswa dengan kemampuan self efficacy sedang pada soal 3

Berdasarkan pada gambar 8 di atas menunjukkan siswa dengan kemamuan self efficacy sedang memberikan jawaban dari soal yang diberikan. Siswa menuliskan bagaimana prosedur penyelesaian secara sistematis dengan menerapkan konsep yang jelas dan diakhir jawaban memberikan penjelasan bagaimana menentukan penyelesaian secara tepat dan benar. Analisis jawaban menunjukkan bahwasannya siswa dengan kemampuan self efficacy sedang sudah mampu memberikan penjelasan secara lebih lanjut untuk menyelesikan soal yang terdapat pada indikator 3 .

3) Analisis jawaban siswa dengan kemampuan self efficacy rendah (C1)

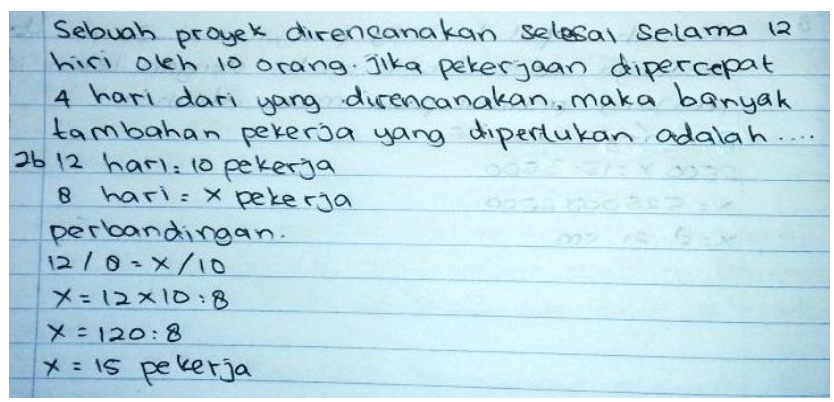

Gambar 9. Jawaban siswa dengan kemampuan self efficacy rendah pada soal 3

Berdasarkan pada gambar 9 di atas menunjukkan siswa dengan kemampuan self efficacy rendah dapat menjawab pertanyaan. Siswa menuliskan bagaimana prosedur penyelesaian secara sistematis dengan menerapkan konsep yang jelas, tetapi diakhir jawaban siswa menganggap bahwa hasil yang diperoleh adalah jawaban yang ditanyakan. Dengan demikian, siswa belum mampu menyelesaikan soal yang diberikan. Analisis jawaban menjelaskan siswa dengan kemampuan self efficacy rendah belum mampu memberikan penjelasan secara lebih lanjut pada saat menyelesaikan soal yang terdapat pada indikator 3 . 


\section{d. Indikator soal nomor $\mathbf{4}$ adalah menyimpulkan}

Soal nomor 4 yang dijadikan sebagai indikator 4 yaitu menyimpulkan sebagai berikut:

Mungkinkan suatu persegi mempunyai keliling sama dengan persegi panjang? Sertakan alasan. Jika memungkinkan, tentukan ukuran pada persegi panjang maupun persegi tersebut!

1) Analisis jawaban siswa dengan kemampuan self efficacy tinggi (A1)

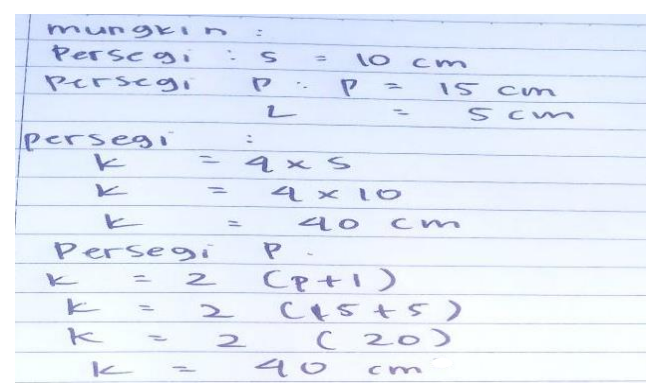

Gambar 10. Jawaban siswa dengan kemampuan self efficacy tinggi pada soal 4

Berdasarkan pada gambar di atas menunjukkan siswa dengan kemampuan self efficacy tinggi (A1) mendeskripsikan alternatif kemungkinan dari soal yang diberikan dengan sisi persegi adalah $10 \mathrm{~cm}$ dan hasil keliling persegi adalah $40 \mathrm{~cm}$. selanjutnya, persegi panjang dengan lebar 5, dan panjang $25 \mathrm{~cm}$, maka hasil keliling persegi panjang yaitu $40 \mathrm{~cm}$. analisis jawaban menunjukkan siswa yang berkemampuan self efficacy tinggi sudah mampu menjelaskan kesimpulan pada saat menyelesaikan soal yang terdapat pada indikator 4 .

2) Analisis jawaban siswa dengan kemampuan self efficacy sedang (B1)

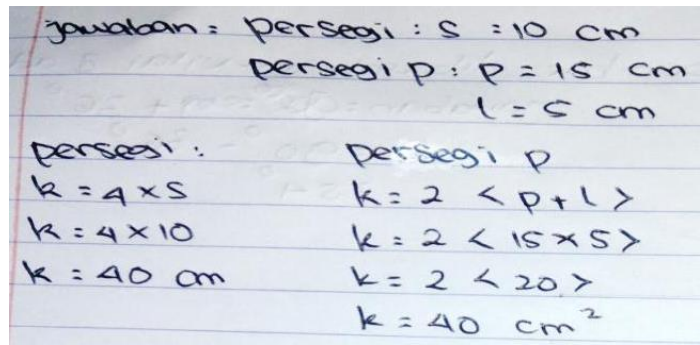

Gambar 11. Jawaban siswa dengan kemampuan self efficacy sedang pada soal 4

Berdasarkan gambar di atas menjelaskan bahwasannya siswa dengan kemampuan self efficacy sedang dapat menyediakan alternatif kemungkinan dari soal dengan sisi persegi adalah $10 \mathrm{~cm}$ dan hasil keliling persegi adalah $40 \mathrm{~cm}$. Kemudian pada bidang persegi panjang dengan panjang sebesar $15 \mathrm{~cm}$ dan lebarnya $5 \mathrm{~cm}$ sehingga diperoleh hasil keliling persegi panjang $40 \mathrm{~cm}^{2}$. Dalam hasil ini, siswa salah dalam menentukan satuan dari keliling persegi panjang. Analisis jawaban menunjukkan bahwasannya siswa dengan kemampuan self efficacy sedang sudah mampu menjabarkan kesimpulan pada saat menyelesaikan soal yang terdapat pada indikator 4 meskipun terdapat kesalahan dalam menentukan satuan keliling pada persegi panjang. 
3) Analisis jawaban siswa dengan kemampuan self efficacy rendah (C1)

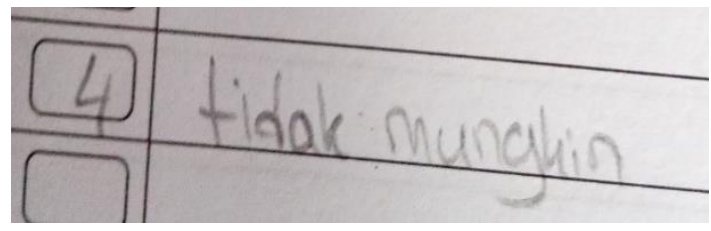

Gambar 12. Jawaban siswa dengan kemampuan self efficacy rendah pada soal 4

Berdasarkan pada gambar di atas menjelaskan bahwa siswa dengan kemampaun self efficacy rendah menjawab tidak munhgkin. Siswa tersebut membuat kesimpulan bahwa persegi panjang dan persegi tidak mungkin mempunyai nilai keliling sama, maka siswa tersebut tidak melanjutkan jawaban atau memberikan contoh ukuran pada persegi panjang dan persegi. Hasil dari analisis jawaban menunjukkan siswa dengan kemampaun self efficacy rendah belum mampu dalam menyimpulkan secara benar dalam menyelesaikan soal yang terdapat pada indikator 4 .

Kemudian hasil dari peneliti melakukan analisis terhadap kemampuan siswa dalam berpikir secara ktiris matematis dari 25 siswa dengan kategori self efficacy tinggi, sedang, rendah pada diagram di bawah ini:

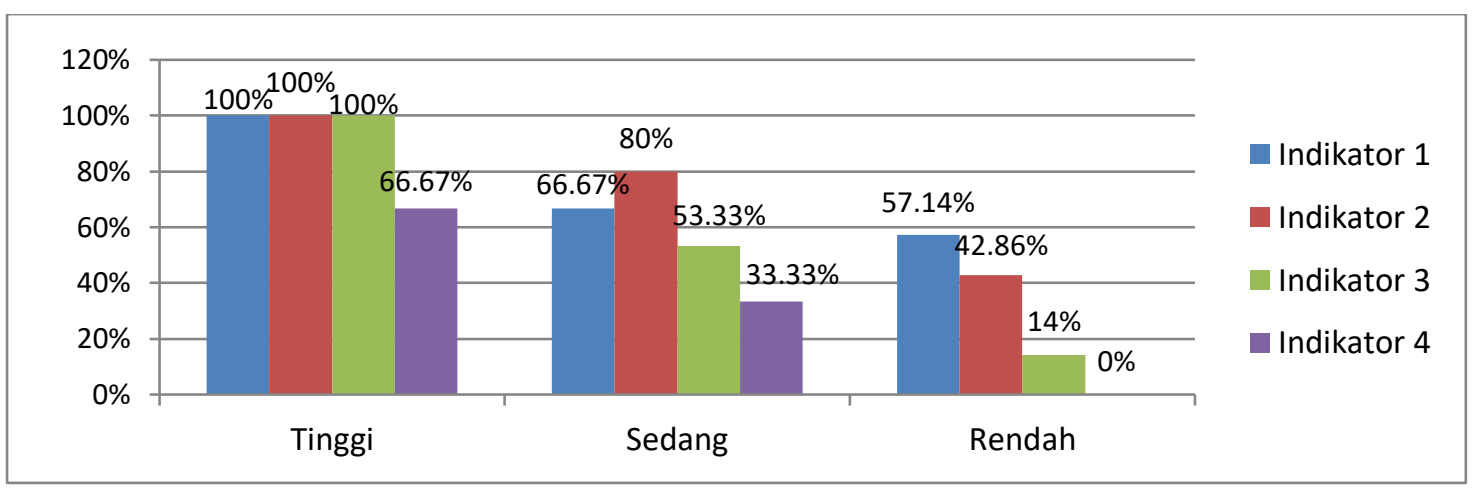

Diagram 1. Analisis pada kemampuan berpikir kritis matematis berdasarkan pada tingkat self efficacy tinggi, sedang, rendah

Berdasarkan diagram 1 menunjukkan bahwa dari 3 orang siswa yang berada pada tingkat self efficacy tinggi diketahui bahwasannya pada setiap indikator berpikir secara kritis matematis pada indikator 1 (memberikan deskripsi sederhana) sebanyak 3 siswa atau 100\%, untuk indikator 2 (memberikan strategi dan taktik) sebanyak 3 siswa atau 100\%, untuk indikator 3 (membuat penjelasan lebih lanjut) sebanyak 3 siswa atau $100 \%$, dan untuk indikator 4 (membuat kesimpulan) sebanyak 66,67\%. Kemudian, 15 siswa yang berada pada self efficacy sedang diketahui bahwasannya disetiap indikator kemampuan berpikir secara kritis matematis untuk indikator1 (memberikan deskripsi sederhana) sebanyak 10 siswa atau 66,67\%, untuk indikator 2 (memberikan strategi dan taktik) sebanyak 12 siswa atau 80\%, untuk indikator 3 (membuat penjelasan lebih lanjut) sebanyak 8 siswa atau 53,33\%, dan untuk indikator 4 (membuat kesimpulan) sebanyak 5 siswa atau 33,33\%. Selanjutnya, 7 siswa pada kategori tingkat self efficacy tinggi diperoleh bahwa dari setiap indikator kemampuan berpikir kritis matematis untuk indikator 1 (memberikan penjelasan secara sederhana) sebanyak 4 siswa atau 57,14\%, untuk indikator 2 (memberikan strategi dan taktik) sebanyak 3 siswa atau 42,86\%, 
untuk indikator 3 (membuat penjelasan lebih lanjut) sebanyak 1 siswa atau 14,29\%, dan untuk indikator 4 (membuat kesimpulan) sebanyak 0 siswa atau 0\%. Dengan demikian, dapat ditarik kesimpulan bahwasannya siswa dengan kemampaun self efficacy tinggi memperoleh nilai rata rata sebesar 91,6\% dengan kategori yang dihasilkan yaitu baik, siswa dengan self efficacy sedang memperoleh nilai rata -rata sebesar 58,33\% dengan kategori yang dihasilkan yaitu cukup, kemudian siswa dengan kemampuan self efficacy yang rendah memperoleh nilai rata-rata sebesar 28,57\% dengan perolehan kategori rendah.

Dari indikator di atas jika dikaitkan dengan matematika, maka kita ketahui siswa dengan kemampuan berpikir kritis akan membantu dalam memecahkan persoalan matematis yang mana menuntut siswa tersebut agar mampu merumuskan serta menafsirkan persoalan sehingga nantinya mereka dapat membuat strategi untuk mengatasi masalah atau pun dalam penarikan kesimpulan. Dalam tuntutan belajar mandiri, siswa dengan kemampuan berikir kritis tinggi dapat mempertimbangkan informasi yang didapat, merumuskan pertanyaan, mengidentifikasi dan menganalisis permasalahan serta memberi alasan terhadap keputusan yang ia ambil. Kemampuan ini sangatlah penting dimiliki oleh setiap siswa pada saat mengikuti aktivitas pembelajaran secara daring, hal ini dikarenakan akan lebih mempermudah dalam berkomuniasi antara pendidik dan siswanya sehingga dapat berjalan efektif dan menghasilkan sesuatu yang lebih maksimal. Dengan demikian, kemampuan berpikir kritis berpengaruh positif serta membangun karakter siswa.

Hal ini menciptakan siswa lebih fokus dan maksimal dalam mencapai keberhasilan dalam belajar. Kemampuan berpikir kritis melatih seseorang untuk lebih memahami konsep daripada hanya mengingat. Dalam belajar matematika, siswa diharapkan mampu menerapkan konsep, rumus, teorema, merancang solusi, menganalisis, mengevaluasi dan menyimpulkan soal yang diberikan. Namun, ketika siswa merasa kurang efektif dalam belajar secara daring akan menimbulkan tidak berkembangnya kemampuan berpikir secara kritis. Siswa dengan kemampuan berpikir yang rendah cenderung mengidentifikasi soal hanya berdasarkan fakta (Koto \& Priyanda, 2021). Kemudian, siswa yang berkemampuan berpikir tinggi akan lebih peka kepada persoalan yang muncul, sehingga mereka mampu menelaah informasi secara lebih baik. Ketika siswa tersebut dihadapkan kepada persoalan matematika yang dirasa cukup sulit maka kemampuan berpikir kritis yang dimiliki akan sangat dibutuhkan pada saat menganalisa (Nurazizah \& Nurjaman, 2018). Siswa yang terbiasa berpikir tinggi akan mampu dalam memecahkan persoalan matematis yang ada dalam aktivitas keseharian baik yang bersifat rutin maupun non rutin, sehingga kemampuan berpikir kritis tersebut akan menjadi penting karena akan dapat menyebarkan energi positif terhadap prestasi belajar.

\section{KESIMPULAN DAN SARAN}

Berdasarkan pada hasil penelitian maupun analisis data yang dihasilkan pada penelitian terkait kesulitan siswa dalam menyelesaikan persoalan keterampilan berpikir secara kritis matematis yang mana disebabkan oleh rendahnya self efficacy. Siswa yang mempunyai self efficacy tinggi akan mampu dalam menyelesaikan soal secara teliti, namun sebaliknya siswa dengan self efficacy rendah cenderung kurang baik dalam menyelesaikan soal. Oleh karena itu, untuk dapat meningkatkan kemampuan siswa dalam berpikir secara kritis matematis, maka tenaga pendidik ataupun guru terlebih dahulu harus meningkatkan self efficacy siswa dalam aktivitas pembelajaran matematika. 


\section{DAFTAR PUSTAKA}

Agusman. (2016). Desain Model Pembelajaran Matematika yang Mengembangkan Kemampuan berpikir Kritis. Jurnal Pendidikan Matematika, 2(2), 111-121.

Arikunto, S. (2019). Prosedur Penelitian. Jakarta: Rineka Cipta.

Assidiqi, M. H., \& Sumarni, W. (2020). Pemanfaatan Platform Digital di Masa Pandemi Covid19. Prosiding Seminar Nasional, 298-303.

Bandura, A. (1997). Self-Efficacy: The Exercise of Control. W. H. Freeman and Company.

Depdiknas. (2006). Permendiknas No 22 Tahun 2006 Tentang Standar Isi.

Dwidarti, U., Mampouw, H. L., Setyadi, D., Kristen, U., \& Wacana, S. (2019). Analisis Kesulitan Siswa dalam Menyelesaikan Soal Cerita pada Materi Himpunan. Journal Cendekia: Jurnal Pendidikan Matematika, 3(2), 315-322.

Ennis, R. H. (1996). Critical Thinking Dispositions: Their Nature and Assessability. Informal Logic, 18(2), 165-182. https://doi.org/10.22329/il.v18i2.2378

Fauzy, A., \& Nurfauziah, P. (2021). Kesulitan Pembelajaran Daring Matematika Pada Masa Pandemi COVID- 19 di SMP Muslimin Cililin. Jurnal Cendekia: Jurnal Pendidikan Matematika, 5(1), 551-561.

Gideon, S. (2020). Komparasi Edmodo, Google Classroom dan Schoology Sebagai Media PJJ Online Pada Mata Kuliah Fisika 1. Indonesian Journal of Natural Science Education (IJNSE), 3(2), 324-330.

Hadiprasetyo, K., Exacta, A. P., \& Maharani, A. (2020). Analisis Kesulitan Belajar pada Mata Pelajaran Matematika dengan Pembelajaran Dalam Jaringan (Daring) Selama Masa Darurat Covid-19 Pada Siswa Kelas VIII SMP Negeri 2 Ngadirojo Tahun Ajaran 2019/2020. Jurnal Pendidikan, Sains Sosial Dan Agama, 6(2), 6-12.

Handayani, F. (2020). Building Students ' Critical Thinking Skills through STEM-Based Digital Literacy during the Pandemic Period Covid 19. CENDEKIAWAN, 2(2), 69-72. https://doi.org/https://doi.org/10.35438/cendekiawan.v2i2.184

Hartini, T., Misri, M. A., \& Nursuprianah, I. (2018). Pemetaan Kemampuan Hots Siswa Berdasarkan Standar Pisa Dan Timss Untuk Meningkatkan Mutu Pendidikan. Eduma: Mathematics Education Learning and Teaching, 7(1), 83-92. https://doi.org/10.24235/eduma.v7i1.2795

Hasmatang. (2019). Pentingnya Self Efficacy pada Diri Peserta Didik. Prosiding Seminar Nasioal Biologi VI, 1, 296-298.

Hendriana, H., Euis Eti Rohaeti, E. E., \& Sumarmo, U. (2017). Hard Skills dan Soft Skills Matematik Siswa. Bandung: Refika Aditama.

Herliandry, L. D., Nurhasanah, Maria Enjelina, S., \& Kuswanto, H. (2020). Pembelajaran Pada Masa Pandemi Covid-19. Jurnal Teknologi Pendidikan, 22(1), 65-70.

Indahsari, I. N., Situmorang, J. C., \& Amelia, R. (2019). Analisis Kemampuan Pemecahan 
Masalah Matematis dan Self-Efficacy Siswa MAN. Journal On Education, 1(2), 256-264.

Koto, M. J., \& Priyanda, R. (2021). Analisis Kemampuan Critical Thinking Matematis Siswa dalam Penggunaan Perangkat Pembelajaran Berbasis Virtual Di SMA Negeri 3 Bangko Pusako. Prosiding Seminar Nasional Peningkatan Mutu Pendidikan, 2(1), 159-164.

Muhtadi, D., Supratman, \& Hermanto, R. (2019). The Students' Mathematical Critical Thinking Process Reviewed From The Cognitive Style. Journal of Physics: Conference Series, 1188(1), 1-7. https://doi.org/10.1088/1742-6596/1188/1/012082

Noer, S. H. (2018a). Desain Pembelajaran Matematika. Yogyakarta: Graha Ilmu.

Noer, S. H. (2018b). Guided Discovery Model: An Alternative To Enhance Students' Critical Thinking Skills and Critical Thinking Dispositions. Jurnal Riset Pendidikan Matematika, 5(1), 108-115. https://doi.org/10.21831/jrpm.v5i1.16809

Nurazizah, S., \& Nurjaman, A. (2018). Analisis Hubungan Self Efficacy Terhadap Kemampuan Berpikir Kritis Matematis Siswa pada Materi Lingkaran. Jurnal Pembelajaran Matematika Inovatif, 1(3), 361-370. https://doi.org/10.22460/jpmi.v1i3.361-370

Puspaningtyas, N. D. (2019). Berpikir Lateral Siswa SD Dalam Pembelajaran Matematika. MATHEMA JOURNAL, 1(1), 24-30.

Ramadhani, R. (2020). Pengukuran Self-Efficacy Siswa Dalam Pembelajaran Matematika Di SMK Negeri 6 Medan. Jurnal Pionir LPPM Universitas Asahan, 7(3), 32-38.

Sari, T. T. (2020). Self-Efficacy dan Dukungan Keluarga Dalam Keberhasilan dari Rumah di Masa Pandemi COVID-19. 4(2), 127-136.

Slavin, R. E. (2006). Educational Psychology: Theory and Practice (8th Edition). Boston: Pearson Education International.

Solikhin, \& Fauziah, A. N. M. (2021). Analisis Kemampuan Berpikir Kritis Siswa SMP Pada Pelajaran IPA Saat Pembelajaran Daring Selama Pandemi Covid-19. PENSA E-JURNAL: PENDIDIKAN SAINS, 9(2), 188-192.

Suharna, H., \& Abdullah, N. (2020). Kemampuan Berpikir 4C Matematika dalam Pembelajaran di Masa Covid-19 Terutama Di Era New Normal. Jurnal Matematika Dan Pendidikan Matematika, 9(2), 178-185.

Utami, Y. P., Alan, D., \& Cahyono, D. (2020). Study At Home: Analisis Kesulitan Belajar Matematika Pada Proses Pembelajaran Daring. Jurnal Ilmiah Matematika Realistik (JI$M R), 1(1), 20-26$. 